\title{
Prosperity and health ministry as a coping mechanism in the poverty and suffering context of Zimbabwe: A pastoral evaluation and response
}

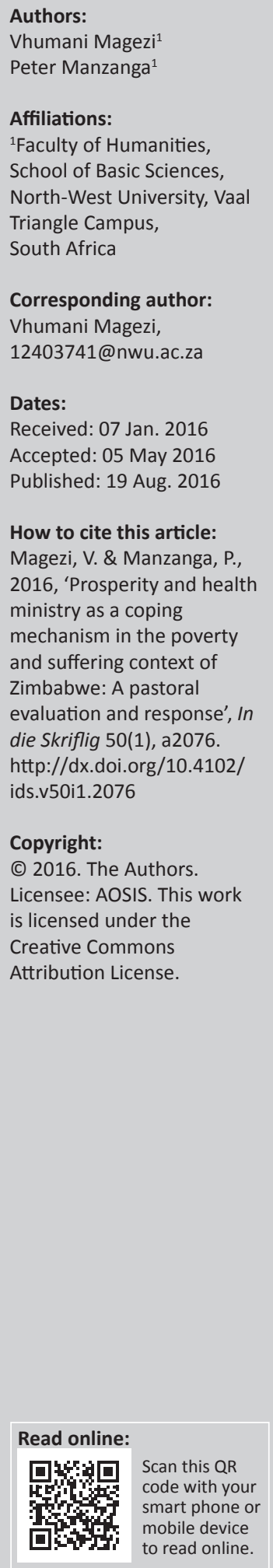

Preaching on prosperity and health has significantly increased in Zimbabwe. Yet, poverty and suffering are also increasing, which is a contradiction. The preaching gives 'hope' of prosperity, wealth, health and success to its followers. The emerging question, however, is the following: What kind of hope is given? This article considers the Zimbabwean context of suffering and poverty, and the coping that arises from the Prosperity Gospel Movement. It is argued that this movement tends to grow rapidly where there are challenges such as poverty, unemployment and health problems. The article discusses prosperity-gospel trends in Zimbabwe and the history and tenets of the prosperity gospel. It also suggests reasons for the rise of the movement. The article concludes by providing an evaluation of the movement and offering a pastoral response.

\section{Introduction and background}

The economic, governance and social challenges experienced in Zimbabwe in the past years since 1995 have resulted in immense poverty and suffering (Mohan 2015). The unemployment rate has kept on soaring despite measures being implemented to alleviate it. Poverty and unemployment are endemic in Zimbabwe, driven by a shrinking economy. Statistics differ and are sometimes manipulated for political reasons. Poverty is said to be close to $80 \%$. Unemployment is ranked as the world highest - at over 90\%. In 2000 the unemployment rate was said to be at $80 \%$ (Freeth 2015). The Zimbabwean Daily News (Chawafambira 2013) reported that 900000 people out of a population of 13 million were estimated as formally employed. A large number of Zimbabweans are currently losing jobs, because companies are closing down (Chawafambira 2013). Research analysis, conducted by Sinthia Chiumia (2014), grappled with the wide variations in the percentages reported on unemployment. She commented that unemployment percentages have been rated as low as 4\% and as high as 95\%. In 2012 unemployment was rated at between 80 and 90\%. The National Association of Non-Governmental Organisations (NANGO) rated it at 95\%. Given the inconsistencies in the unemployment figures, Chiumia (2014:1) concluded that, 'the parlous state of Zimbabwe's economy and unemployment levels are certainly extremely high'.

In such a context, the purpose for living becomes critical. A responsive theology of prosperity preaching has proliferated to address people's challenges and experiences. Before the crisis period mentioned above and in recent years, prosperity gospel had gained popularity. Therefore, there is need to evaluate prosperity gospel preaching in Zimbabwe in order to provide pastoral insight and direction as well as to propose alternative constructive messages for coping.

A constructive theology avoids simplistic solutions to suffering in which God's image (conception of God) as a Father Christmas is made prevalent and nurtured (Louw 1998:330-334). By constructive we refer to a theology that can help people to have appropriate God concepts and understanding that assist in meaningful healing rather than a utopian theological approach. A utopian theology provides an inappropriate picture of life in the world whereby life is always viewed as blissful and free from suffering. Hence, a constructive (or appropriate) theology is a theological approach that views life within an appropriate Christian framework where good and bad, life and death, joy and suffering co-exist (paradox theology). To illustrate paradox theology, the crucifixion of Jesus is viewed both as seemingly a defeat and lost hope for humanity, and yet, it is precisely the victory and salvation of humanity. Thus, a constructive theology avoids a God image of God as distant and uninvolved. It is about real life. In a distant and uninvolved God image, God's involvement in suffering is spiritualised to the extent of being irrelevant to practical living. Eschatology is viewed only as a dimension that shall be ushered in by Parousia [second coming of Jesus], and the notion of a kingdom now (realised eschatology) is totally downplayed. 
An appropriate (constructive) theology has a moderated realised eschatology as a space where challenges are part of life. That way, suffering is not spiritualised, but viewed as part of practical life. In this space, God is immanent (not distant) and, at the same, he is transcendent (distant in and different from us as humans).

Holding only to a futurist view of eschatology (kingdom not yet) suggests that God intervenes at the end of the age. This image can be drawn from biblical texts such as Revelation 21:4 where God promises to wipe away all the tears of believers at the end of the age. This stands in stark contrast to the doctrine of God's transcendence and immanence. The paradoxical transcendence and immanence of God is Christ's guaranteed timeless promise of his presence, as Jesus in Matthew 28:20 promised to be always present with his people until the end of the age. Through the dynamic presence of the Holy Spirit within believers' lives, God is not distant from his people in this interim period where they encounter various contextual sufferings and challenges (Fee 1994:8; Torrance 2009:294). However, the dangers are to over-emphasise God's involvement in the sufferings of people in this era of Christianity, or to view God as a big brother who intervenes at every moment to push away and trample on the challenges of life that we encounter (Golo 2013:368).

To overcome the above theological challenges, practical theology should imagine fresh ways of thinking of faith care as life care in contexts of suffering. Faith care as life care encompasses a constructive theological perspective in which salvation of the soul and the body are viewed holistically (the total being of humankind) (Dames \& Dames 2009:18; Louw 2004:34). In other words, faith care must offer holistic care that encompasses both physical and spiritual salvation instead of limiting Christ's salvation to sin or the soul (Aho Ekue 2005:104; Mbiti 1986:158-159).

However, the challenge of faith care as life care is to develop a theological perspective that fosters realistic hope founded on a constructive and appropriate perspective of God. This challenges practical theology to be evaluative of theological perspectives. Failure to do this will result in a 'bubble faith' that is devoid of an appropriate and constructive conception of God's working as revealed in Scripture. 'Bubble faith' categories provide simplistic solutions to people's challenges and suffering, while non-contextual categories provide 'zombie' categories of understanding God. Concerning 'zombie' categories, Reader (2008:4) and Louw (2011:1), describe them as concepts that no longer do justice to the world we experience and yet are difficult to abandon because of tradition and also because they are not yet totally redundant. 'Zombie' categories can therefore be described as the 'living dead', the tried and familiar frameworks of interpretation that have served us well for many years and continue to haunt our thoughts and analysis as Christians, even though they are embedded in a world that is passing away before our eyes.

In view of the above challenges in the Zimbabwean situation, 'prosperity gospel seems to provide believers with hope.
Rather than glorifying the grace of God in salvation, this newly conceived gospel focuses on human potential ${ }^{1}$ for successful living, emphasizing health and wealth' (Sarles 1986:329). It is common knowledge that once people are unemployed, the downward spiral of poverty keeps on growing and affecting the nation. Maxwell (1998) comments that:

Zimbabweans are not getting richer. Inflation continues to increase along with unemployment as the gap between rich and poor grows ever wider. Since 1995 there have been waves of strikes by civil servants, doctors and nurses, construction workers and security guards. Nevertheless, as an explanation for, and response to, misfortune, Spirit of Poverty continues to have great appeal. (p. 369)

Promises of the Prosperity Gospel Movement sound highly convincing to the suffering and unemployed. Who would not want a decent job after being redundant for a decade? But are the promises realistic, true or false? In a recent article by Wafawarova (2015) who is a respected religious scholar, in The Herald (the most widely read newspaper), stated that the:

... prosperity gospel has this ironic effect of keeping people in poverty. When promises fail to materialize, as is the case ... most of the time, the follower is simply blamed for not giving enough money in offering, or for lacking in faith. (p. 1)

The more pressing questions are: Why are the fortunes of people not changing and if their fortunes change, are Christian health and prosperity then measured by the absence of problems? Is God most glorified in us as Christians when we have splendid health and material blessing, or in the midst of pain and loss? (Piper 2012). The teaching of prosperity gospel seems to provide hope in times of desperation, but what kind of hope: true or false hope? Why do people find this gospel appealing in their times of suffering? The level of poverty is continuing unabated in the country and the fortunes of people are not changing. The major premise of this article is therefore that one needs to develop and cultivate a constructive approach to life's challenges as taught in the Bible in order to respond to the challenges of the wealth, health and prosperity gospel.

\section{Trends of the prosperity gospel in Zimbabwe}

Prosperity gospel tendencies in Zimbabwe are manifested in three major (among others) preachers: the United Family International Church, led by Prophet Emmanuel Makandiwa; the Prophetic Healing Deliverance Ministries, led by Prophet Walter Magaya; and Spirit Embassy (on the decline), led by Uebert Angel. Currently the more prominent and vibrant

1.Man is viewed as a 'god', because he was created in the image of God. Therefore, man has an innate power to recreate just like his maker through positive faith. This is proven through words of a prosperity gospel preacher 'Blasphemy is when you is proven through words of a prosperity gospel preacher, "Blasphemy is when you go against what God has said about your true self! OOOOh! We are so unworthy! Shut up with that blasphemy ... You are not a sinner saved by grace. You are sons and daughters of the Most High God! You are gods! You are God's reflection on this planet. For you to say that thing is for you to count the blood of Jesus worthless. His blood was sent to cleanse you of your sin and you going around saying that you are still a sinner! What's the matter with you?' (Wise 2015). 
churches are led by Prophet Makandiwa and Prophet Magaya. All three have many features in common: performing miracles on healing and deliverance; an exceptional number of followers thronging their worship gatherings; the use of objects such as armbands which the followers buy; the use of holy oil and holy water by followers; and a message that is predominantly centred on liberating people from the curse of poverty and sickness.

Prophet Makandiwa is ranked among Africa's five richest pastors by Roy Moyo in an internet article of 15 September 2011. Moyo (2011) says:

Most of Prophet Makandiwa's teachings articulate how Christians can use God's word to start and grow successful businesses ... He inspires followers to appreciate that through prayer, God will bring success to our everyday efforts. Prophet Makandiwa illustrates his point by giving himself as an example. He speaks of his poor upbringing, and how God turned that around ... people are coming from different religious groupings to listen to his phenomenal teachings about the most high God. (p. 1)

Makandiwa started his interdenominational church in 2008, and it became fully operational in 2010 . He is a former pastor of the Apostolic Faith Mission in Zimbabwe (AFM). Makandiwa has hogged the media's limelight with his controversial miracles, which have ranged from 'manhood enlargement', changing people's HIV status, causing the birth of baby after a pregnancy of only three days. Makandiwa performed a miracle that saw some of his followers miraculously finding money in their pockets and their bank accounts. In 2014, he launched the 'miracleworking anointing oil', which was meant to pave the way for the economic advancement of his followers. He had earlier predicted an economic boom for the country that would change the lives of Zimbabweans for the better (Pindula site 2015). Recently, Prophet Makandiwa said he stood by his prophecy that Zimbabwe is sitting on massive untapped oil reserves (The Standard 2015). The prophecy sparked mixed feelings among Zimbabweans, but many are waiting for the result.

Prophet Walter Magaya is also famous for performing miracles and delivering followers from demons. In an internet article in The Zimbabwean (Staff Reporter 2015:1), he is described as generating '... not less than $\$ 2$ million dollars a month, from various merchandise at his church services'; and as having 'serious income-generating strategies'.

The questions at stake, among many, are the following: Why are the bad fortunes of their followers continuing unabated? If their message on prosperity is true, why do we have a large number of people redundant and wallowing in poverty? Is becoming a prophet in modern Zimbabwe always associated with riches? Or is there an assumption that if one is righteous and virtuous, then one will be wealthy? (Talbert 2010:237).

\section{An overview: Prosperity and health gospel teaching}

Faith movement traces its origins ${ }^{2}$ to the American soil and was later conveyed to other parts of the world, promising people health and wealth. Bowler (2010) states that:

This story follows the Faith movement down the many rabbit holes that mark American civil religion. ... the story includes metaphysical religion as key to the telling of American religious history in general, and the American Faith movement in particular. Metaphysical religion focuses on the relationship between the human mind and the spiritual universe, and the transference of energy that links one to another. Metaphysical New Thought infused Christian language with new power as believers came to believe that their minds could alter the material order. Albanese once observed that New Thought sought Mind, while evangelicalism sought Heart. In the end, the prosperity gospel refused to do without either one. (p. 10)

Prosperity gospel is not confined to a special denomination or school of thought. It sprang from the New Thought ${ }^{3}$ Movement that began around 1895. The pioneers of this movement were Emmanuel Swedenborg (1688-1772) and Phineas Quimby (1802-1866) (Jones \& Woodbridge 2011). Among the prominent pioneers of the New Thought Movement was Mary Eddy Baker, $^{4}$ the founder of Christian Science. She developed a trend of thought similar to that of the pioneers of New Thought in that her Christian Science basically represents a denial of the material world (Tucker 1989:149).

Discussing the prosperity movement, Sarles (1986) describes it thus as follows:

It is a broadly based variegated movement that overlaps both the charismatic and non-charismatic spectrums. It seems to be a blending of the positive thinking emphasis of a Norman Vincent Peale or a Robert Schuller and the faith healing ministry of Oral Roberts. (p. 329)

The 20th century saw the coming of Essek William Kenyon, who also brought ideas of 'positive confession' as it relates to Christ's finished work. According to him, such confession could bring emotional and physical aspirations into existence (Phiri \& Maxwell 2007:25).

In the 1930s Kenneth Hagin ${ }^{5}$ (1917-2003) expounded on Kenyon's teaching in his Pentecostal beliefs, which led him to

2.Though its origins lay in the late nineteenth century, the prosperity gospel took root in the Pentecostal revivals of the post-World War II years. It reached maturity by the late 1970 s as a robust pan-denominational movement, garnering a national late 1970 s as a robust pan-denominational movement, garnering a national
platform and a robust network of churches, ministries, publications, and media outlets' (Bowler 2010)

3.Major tenets of New Thought also reflected in the Prosperity Gospel Movements are Infinite Intelligence or God is omnipotent and omnipresent; Spirit is the ultimate reality; True human selfhood is divine; Divinely attuned thought is a positive force for good; All disease is mental in origin; and Right Thinking has a healing effect (see Jones \& Woodbridge 2011)

4.Mary Eddy Baker has been depicted thus: 'the most daring and masculine and masterful woman that appeared on earth in centuries. despite her success in building a religious philosophy and movement that denied the reality of physica building a religious philosophy and movement that denied the reality of physical sickness, she herself was never able to escape debilitating physical problems
(Tucker 1989:149-150).

5.In the 1980s and 1990s, Hagin's radio programme, called 'Faith Seminar of the Air', was heard from coast to coast in the United States and reached over 80 nation worldwide. His other ministries included REHEMA Correspondence Bible School, 
create what later became the Word-Faith movement. Mikhaiel (1992:124) states that he was a well-known personality, not only in the United States but also around the world. Hagin, an Assemblies of God pastor, taught Christians that they could amass riches by building enough faith. He publicised what he called the 'Rhema doctrine', which, according to him, taught that words uttered in faith must be fulfilled. In the 1960s Kenneth Copeland started to teach that faith is a 'force', which must yield material results when confessed out loud. Within decades, Word-Faith had grown into a remarkable off-shoot of charismatic faith (Phiri \& Maxwell 2007:26).

Prosperity theology strongly encourages its followers to engage in rigorous positive thinking, confession and faith to get results from God on their prayers. Phiri and Maxwell (2007:24) note that prosperity teaching is the worst brand of religion to have invaded Africa and actually describe the movement as 'an American export'. Various reasons ${ }^{6}$ by experts have been cited for the spread of the health and wealth movement. The personalities mentioned above could be considered the propagators of the prosperity movement together with people like Bob and Marte Tilton, Jenny Savelle, Francis Hunter and Charles Capps. Contemporary world has Joyce Meyer, Joel Osteen, Bruce Wilkinson, TD Jakes, et cetera - all of them American based. The movement has found a positive reception in the African continent.

\section{Tenets of the prosperity gospel}

The tenets of health and wealth prosperity teaching are the following.

\section{Faith}

The belief system of the Prosperity Gospel Movement traces its roots to Kenneth Hagin, who is the father of the movement. He portrayed a misconstrued understanding of faith. What he calls 'faith' is actually positive thinking. Hagin said (Adeleye 2011):

Did you ever stop to think of having faith in your own faith? Evidently God had faith in His faith because He spoke words of faith and they came to pass ... In other words, having faith in your word is having faith in your faith. That's what you have got to learn to do to get things from God: Have faith in your faith. (p. 62)

In this context, therefore, faith is exercised in order to get things from God.

\section{Positive confession}

The spoken word has the power to translate things into reality. This can be either positive confession or negative confession. The origins of positive confession can be traced back to Kenyon who said, 'A spiritual law that few of us

(footnote 5 continues...)

REHEMA Bible Training Centre, REHEMA Alumni Association, REHEMA Ministerial Association International and Prison Ministry Outreach. According to Mikhaie (1992:124), 'most of the well-known personalities in the faith movement have been influenced by Hagin's teachings'.

6.Phiri and Maxwell (2007:24) cite the following reasons for the spread of this teaching to Africa: (1) American lifestyles have led African believers to equate Christian faith with wealth. (2) Traditional African values often link material success and spiritual success. (3) The African 'Big Man' ideal honours rich, powerful leaders such as prosperity preachers. realise is that our confession rules us' (Atkinson 2008:1). The teaching embedded in this statement is that each time one confesses positively, God realises it. Our confessions 'cause' God to bring into existence what we desire for our lives. Adeleye says that other teachers, like Capps, encourage first visualising, and then speaking into reality, what we desire. This is confirmed in the words of Capps cited by Adeleye (2011):

This is key to understanding the virgin birth. God's word is full of faith and spirit power. God spoke it. God transmitted that image to Mary. She received the image inside of her ... The embryo that was in Mary's womb was nothing more that the word of God. She conceived the word of God. (p. 64).

When people are asked to visualise what they wish from God, then it is no longer biblical faith, but something else. The author of Hebrews in 11:1 gives us a clear definition of what faith is: 'Now faith is the assurance of things hoped for [not visualised], the conviction of things not seen [not visualised]'. Faith must be biblical faith that always acknowledges God as God at all times and it must rest on God - not on what one claims (Heb 11:6). The believer must approach God in total obedience and trust, acknowledging his sovereign will in every situation.

\section{The seed faith principle}

This principle is one of the teachings secretly infiltrating the Protestant churches in Zimbabwe. The principle entails church members being persuaded to bring their money, seeds, poultry, et cetera, to the man of God to be prayed over for multiplication. It assumes that what one gives to God must always multiply and that 'Those that sow big will reap

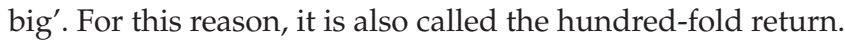
For instance, the common approach used can be summarised in the following 'formula' for seeding and multiplying the little that one may have (MacArthur 1992):

... take out the largest bill or check [cheque] you have ... that $\$ 100$, $\$ 50$, or $\$ 20$ bill ... Hold it in your clean hands and say, 'In Jesus' Name I declare this gift to God's work ... and expect a return of money. Through this Gift of Discernment ... God is showing me a large check coming ... in the next short while. I mean large ... looks like over a $\$ 1000$ dollars. (p. 324)

There is a very thin line in this approach between the prosperity gospel preachers who practice it and magicians. I agree with the four point analysis of the seed faith principle of Adeleye (2011:83-84). He cites why the seed faith ${ }^{7}$ principle is wrong. First, these preachers usurp God's position to conceive 'whatever' and do anything. No room is left for God at all. Second, biblical faith is not about 'conceiving whatever'; it is about putting our confidence in God to be able to accomplish what he wills. Third, the seed faith teaching opposes the truth that our giving to God is first and foremost an act of worship. God is not an insurance

7.In his article entitled 'Five theological errors of prosperity gospel', Adeleye (2011) citing David Jones who notes that 'The driving force behind this teaching on giving is wh prosperity who not the "The drive is what prosperity teacher Robert Tilton referred to as the "Law of Compensation". According to this law, which is purportedly based on Mark 10:30, [13] Christians need to give generously to others because when they do, God gives back more in return. This, in turn, leads to a cycle of ever-increasing prosperity'. 
agent as assumed by the Prosperity Gospel Movement. Fourth, a closer look at Galatians 6:7, used by Oral Roberts as the basis of seed faith principle, shows that the verse is treated out of context.

\section{The deification of man as a 'little god'8}

The man created in Genesis 2:7 by God is viewed as a 'little god' according to the Prosperity Gospel Movement. Morris Cerullo believed that God's purpose was to reproduce himself, and he had this to say (Adeleye 2011):

Did you know that from the beginning of time the whole purpose of God was to reproduce Himself? Who are you? Come on, who are you? Come on, say it: 'sons of God'. Come on, say it ... And as we stand up here, brother, you are not looking at Morris Cerullo, you are looking at God. You are looking at Jesus ... (p. 56)

Passages like John 10:34-35 and Psalm 82:6 are used to propagate this teaching that man is a 'little god'. Any religion that deviates from the core teaching of Scripture drifts towards the exaltation of man and equate him with God. These scriptures must be read in their context to correctly understand what they mean.

\section{Some reasons for the rapid increasing of the prosperity gospel}

Below are the considered reasons that seem to have contributed to the propagation of the Prosperity Gospel Movement in Zimbabwe.

First, the prosperity gospel gives hope to the desperate people. The Lausanne Theology Working Group Statement on the Prosperity Gospel (2010) stated the following regarding prosperity gospel:

We recognize that Prosperity Teaching flourishes in contexts of terrible poverty; and that for many people it presents their only hope, in the face of constant frustration, the failure of politicians and NGOs, etc., for a better future, or even for a more bearable present. (p. 100)

The serious concern is that the fortunes of the followers of this gospel are not changing. Hopes are raised and people keep on expecting. To keep people in the bondage of false hope, the prosperity gospellers have shifted people's minds from God to man-made objects. According to Adeleye (2011):

Magical status is given to things like the bishop's 'mantle', 'anointing oil', 'robes', 'handkerchiefs', 'battles axes' etc., with which delude men to think that they can arouse God to action. Members of some churches believe the lie that if they use 'magical' elements of the communion wine, bread, handkerchiefs, or anointing oil, they will not die until they attain the age of seventy. (p. 38)

8.Theologians who include Tilton, Hagin, Capps and Copeland maintain that man was designed or created by God to be the god of this world. Adam was the god of this world [but he] sold out to Satan, and Satan became the god of this world. We were created to be gods over the earth, but remember to spell it with a little ' $\mathrm{g}$ '. Adam was created in God's class to rule as a god by speaking words. Man was created in the God class. We are a class of gods and God himself spawned us from his innermost being. We are in God; so that makes us part of God (2 Cor 5:17; Biblical innermost being. We are in God;
Discernment Ministries 1996).
People are desperate for answers to life situations and issues. They are also confused and unsure about what is appropriate and inappropriate. There is a strong need from the Protestant churches for an open and sincere assessment of what is happening so as to give a relevant and satisfying response.

The grace of God has been turned into a licence for all kinds of practices (Adeleye 2011:39).

Second, there are appealing parallels between the prosperity gospel and African spirituality. Some African theologians ${ }^{9}$ claim that African Traditional Religion (ATR) serves as a stepping stone for the faith in Christ (Nyirongo 1997:1). Such similarities have been understood to mean that ATR, with its worshiping of ancestors, is synonymous with Christianity.

The first similarity found between ATR and the Prosperity Gospel Movement is the manipulation of the object of worship. The ancestors (ATR) are manipulated by speaking the right words, performing the right rituals and acting appropriately. Wellness in ATR means that one's herd of cattle does well, children marry, deaths in the family are minimal, the field produces good crops, et cetera. The Prosperity Gospel Movement emphasises the same issues that ATR lays emphasis on - through the manipulation of God. Congregants are exhorted to exercise positive confession and speak positively. Once this is done, it is expected that God simply unleashes his blessing upon his people. Both ATR and the Prosperity Gospel Movement teach that negative confession and attitude before the object of worship brings bondage, sickness and poverty. 'But good prayers reach the ancestors and blessings will be received afterward - children, protection or good harvests' (Nyirongo 1997:82).

This similarity serves as a seedbed for the growth of the Wealth Gospel Movement, because the latter offers something 'better' than ATR and the manner in which the objects of worship are approached is the same. Thus, many Zimbabweans who are steeped in ATR see the new gospel movement as a 'glorified' or more 'honed' ATR and easy to accept.

The second similarity is the failure to address the problem of man's sin. ATR and the prosperity gospel do not offer a permanent solution to man's problem of sin. This deficiency results in lack of transformed life, manifested through righteous living and holiness. The Prosperity Gospel Movement places emphasis on people having marriages, the barren having twins, people having new cars, new jobs, good health, et cetera. Dealing with sin in a biblical way as the core is foreign to both. If congregants are not truly saved in a biblical manner they will be tempted to fall back on the former manner of life. According to Gehman (1989):

9.One of these African theologians is Laurenti Magesa, a Tanzanian Catholic Priest who advocates that there are many ways to reach the Throne of Grace, and that ATR is one them. A second one is Bolaji Edowu, who sees ATR as synonymous with is one them. A second one is Bolaji Edowu, who sees ATR as synonymous with Christianity. A third one is S.H. Azeanya who says that in African life and thought are hidden treasure, precious gems ... provided by God for the embellishment of the Gospel. A fourth one is Desmond Tutu, South African Anglican Bishop, who advocates for redeeming hidden treasures in ATR. Last, but not least is John Mbiti, who argues that 'God prepared Africans in their religions; the Gospel is a fulfilment, a completion of their beliefs' (Nyirongo 1997:82). 


\begin{abstract}
... the sons and daughters of the ... Christians borrow ... ways of their fathers and fail to make a personal commitment to Jesus Christ. When boredom and dissatisfaction set in, the natural tendency is to revert to the traditional beliefs and practices. When facing a crisis of life and death, having found no security in Christ, they seek refuge in traditional religion [and the new gospel movement]. (p. 282)
\end{abstract}

Biblical Christianity has, as a pillar, the outright condemnation of sin and offers mankind a way of salvation through Jesus Christ.

The third similarity between ATR and the wealth and health gospel is reverence for the medium (in ATR) and the man of God (prosperity gospel). The medium and the man of God receive reverence because of their assumed direct access to the more powerful deity - more powerful ancestors (in ATR) and God (the Prosperity Gospel Movement). The Prosperity Gospel Movement displays such respect of its 'men of God' by having congregants literally bowing down ${ }^{10}$ when they move to the podium to preach. Some congregations observe absolute silence. Still others go to bed with pictures of the man of God, claiming that as long as they have the pictures they are protected from evil spirits that make them sick and poor (Mushekwe 2013).

From my own analysis and observation, these 'men of God' are committing serious blasphemy by assuming the position of God. Some followers have stickers on their cars written, 'I am the child of the prophet'. Biblically, we have incidences of mere men or angels refusing that kind of respect and directing all such respect to God. This leaves us wondering why these so-called 'men of God' accept that type of respect without pointing their congregants to God. Given this similarity between ATR and the Prosperity Gospel Movement, ATR followers will find it easy to accept the Prosperity Gospel Movement as something better than ATR.

The last similarity relates to exorcism. The medium's responsibility in ATR is to identify and exorcise foreign spirits that might be seeking to harm the family. The same practice is found in the Prosperity Gospel Movement. ${ }^{11}$ A remarkable time in church gatherings is absorbed by exorcising spirits that cause sickness to people and prevent them from prospering. Migration from ATR or other religions to join the new movement is feasible. These similarities provide good environment for the prosperity gospel to copy and grow (Wafawarova 2015).

The third reason I have witnessed is the rapid growth of the African ${ }^{12}$ Initiated Churches (AIC's) with similar practices.

10.Mushekwe (2013:1) wrote, 'During a recent visit to Zimbabwe, Prophet Makandiwa and fellow church members knelt on their knees at the Harare International Airport when Boateng arrived for a three-day spiritual conference in Chitungwiza at the UFIC Basilica.'

11.'Traditional rituals that would otherwise be dismissed as diabolical and demonic have become acceptable practice in pursuit of the materialistic objectives of prosperity gospel. Pastors and prophets now pour libations on the ground as a prosperity gospel. Pastors and prophets now pour libations on the ground as a way of enhancing church growth, and bottles of oil, sand, water and other such substances are given to believers as tools of bringing the much-sought-after alongside hand bangles, handkerchiefs and similar objects' (Wafawarova 2015).

12. Here I refer to the Apostolic Sects in Zimbabwe.
The extremely fast growth rate of the (AICs) in Zimbabwe has also provided a positive context for the blossoming of the prosperity gospel. The AICs have prophets and founders who give members counsel and guidance in spiritual matters. Some 'prophets' in AICs instruct some of their congregants with chronic illnesses to cease taking antiretroviral drugs, insulin injections and tablets, cancer medications, et cetera. The reason is the claims from the 'prophets' that God will heal them. There are relapses and deaths resulting from these supposed healings. A serious concern has been registered by the government over these assumed healings that continue to claim the lives of many in the AICs.

The prosperity gospel is similar in its approach to the healing of the sick. Just like in AICs, congregants have died or been rescued by medical doctors. An appeal has been sent to church leaders to stop making such claims of supposed healings among congregants. Zvauya and Muperi (2015) point out in their article that:

Mgcini Sibanda, ZNNP+ programmes officer, told the thematic committee on HIV/Aids in Parliament yesterday that many people living with HIV were dying after getting bad advice from faith healers ... to stop taking antiretroviral drugs ostensibly because they have been healed ... Health minister David Parirenyatwa has called for the arrest of prophets claiming to possess divine power to treat terminal diseases such as cancer and Aids ... Some churches, especially Pentecostal churches, are discouraging HIV-positive people from taking medication in the name of holy waters and oils, and are thereby exposing them to opportunistic infections. (p. 1)

The movement looks very much like a more glorified AIC in that it seems to have instant answers for congregants' poverty and suffering. The use of charms in the AICs is compensated for by the introduction of neatly bottled holy water obtainable from the shops and anointing oil, armbands, et cetera. Thus, prevalence of AICs serves as a context for the sustenance and growth of the Prosperity Gospel Movement in Zimbabwe.

\section{Biblical evaluation of the prosperity and health gospel}

Witherington (2010), has expressed the opinion that:

\begin{abstract}
It is perhaps one of the greatest tragic ironies imaginable that the teaching of Jesus has been used by affluent modern Christians to justify the lifestyles of the rich and famous. This is the very same Jesus who said 'Blessed are the poor' and warned 'Do not store up treasures on earth'. Simple phrases like 'You have not because you ask not' or 'ask (in faith) and you shall receive' have been turned into mantras that are thought to produce nearly instant material benefits. (p. 57)
\end{abstract}

The abuse of scripture on prosperity and health propels us to briefly study what the Bible teaches on this subject. While this section is extremely important, it will not be exhaustive in this space of a limited article. Two relevant questions will be discussed in this section. 


\section{What do 'being prosperous' and 'health in Christ' practically mean?}

Jesus' teaching on being prosperous and health transcended the worldly understanding of being prosperous and healthy. According to Jesus, life is more than just being content with material wealth and physical health. He taught that the world and its riches are transient. Thus, people should strive for something that lasts into eternity.

\section{Witherington (2010) expresses this very well:}

\begin{abstract}
Luke, more than any other New Testament writer, uses salvation language in both senses the term had in the Greco-Roman world, where salvation could mean literal healing or rescue from some danger as well as redemption in a theological sense. And here we note that while theological salvation and physical health in the literal sense often go together in Luke-Acts (a person is healed or rescued as well as saved in the more spiritual sense), salvation and wealth typically do not. (p. 93)
\end{abstract}

The understanding we get from Jesus' teaching in Luke is that people who have come to know Christ personally should use their material blessing and all they have to God's glory.

Jesus is not against Christians being prosperous (materially) and enjoying good health. But he urges Christians not to '... store up ... treasure on earth, where moth and rust destroy, and where thieves break in and steal' (Mt 6:19). ${ }^{13}$ He challenges people to put their core focus on God and not money (Mt 6:24). Healing was part of Jesus' ministry. He had concern for the infirmities of people (Lk 4:38-44; 8:1-3). However, healing and the exorcism of demons were not ends in themselves, as they are in prosperity and health gospel. At the centre of Jesus' mission, the healed were pointed to him so they could put their faith in him. During the biblical apostolic era, attention was put on people having a saving relationship with Jesus. Paul advised Timothy to take a little wine for his infirmity (1 Tm 5:23). Yet, the same Paul had healed many. In 2 Timothy 4:20, Paul left Trophimus sick in Miletum. Why did Paul not heal the two men he dearly loved?

Being prosperous in Christ means to have a saving relationship with him and use what he has blessed us with for the benefit of others and ultimately his Kingdom. Witherington (2010) has this to say:

\begin{abstract}
... Jesus brought an economic reversal of fortunes. It is also striking that in the Lukan version of the Sermon on the Mount we find these words: 'And if you lend to those from whom you expect a repayment, what credit is that to you? ... But love your enemies, do good to them, and lend to them without expecting to get anything back. Then your reward will be great ...' (Luke 6:34-36). (p. 93)
\end{abstract}

Patrons are actually urged to share their possessions with those in need and to expect nothing from them. Jesus' ministry and teaching was against the quid pro quo [getting one thing in return for another] relationship. Whether they

\footnotetext{
13.Exegesis of these passages could have been done, but space constraints of the article do not allow for such engagement.
}

are talking about faith, prayer, Abrahamic Covenant, atonement, giving, et cetera, prosperity teaching expects something in return (Jones \& Woodbridge 2011).

It is also important to note that being prosperous and healthy in Christ do not mean the absence of life- threatening situations. It means practically facing and going through such situations while seeking God- honouring solutions. Godly people suffered persecution. 1 John 3:12 shows that Abel was murdered for his righteousness. In Psalm 44:22 the righteous are described as sheep for the slaughter. Job was righteous, upright and feared, but he suffered (Job 1:1). Through his harrowing experience he sought for Godhonouring solutions. He did his best to remain steadfast and got blessed (Young 2015:145-146). This does not mean that suffering must always end with blessings or that God takes away every suffering. He allows certain life-threatening situations to stay with us. For example, in 1 Corinthians 12:7-10, Paul begged God to have the thorn in his body removed. But God taught Paul that his grace was enough for him. Paul had to depend on God, realising that his strength came from God. The grand example we could cite is that of Christ who had committed no sin and was sinless, but suffered (1 Pt 2:22-24). Hebrews 11 has a list of Godly people that suffered. Since the creation of the world, there has never been a time when people were spared from suffering. In fact, Jesus warned of a time of great tribulation, worse than any other time in all history (Mt 24:21; Young 2015:147).

Conclusively, being prosperous and healthy in Christ practically mean to have faith in him and obey him personally. Prosperous and healthy people should use material blessings and the health God gives for his glory. Having material prosperity and good health does mean the exclusion of life-threatening situations. God allows adverse situations in life for his purposes to be achieved. God is most glorified in us, not when we have material possessions and good health, but when we obey him in the midst of pain, loss and need - and still trust him as God (Piper 2012). Luke 6:20 pronounces a blessing on the 'poor' and 'those who hunger now'. In Kvalbein's view (2000):

The text no doubt refers to socio-economic poverty and physical hunger; those who now are poor, hungry, weeping and persecuted will be raised to glory and enjoy abundance of the kingdom of God. (pp. 689-690)

\section{How should resources, and desire for them, be viewed?}

Golo (2013) notes that:

... prosperity is not alien to the African. The notion of salvation among the indigenous African people emphasizes enjoyment of abundant life, prosperity, vitality, financial and material security, and what Larbi calls the 'equilibrium of the cosmos'. (p. 375)

Thus, desire for resources in mankind is innate. The 'equilibrium of the cosmos' has been distorted through the fall of man in Genesis 3. It is not God's will for his people to live in abject poverty. Desire for material wealth is not inherently wrong. 
The problem arises when there is an over-emphasis on material blessing at the expense of faith in God. Resources or material blessing are not an end in themselves. Trust in God should motivate one to say, 'Give us each day our daily bread' (Lk 11:3). The plea in Jesus' prayer is that life is more than food; it comprehensively covers all the necessities of life. We must pray and enlarge our thoughts as we trust God to provide for our needs (Isaak 2006:1226). If God provides for our resources beyond what we ask for, girded under our minds should be a humble and generous attitude around what the Lord has blessed us with.

The parable of the rich fool (Lk 12:13-21; cf. Ps 14:1) shows that material prosperity should not be used with selfish motives. The man projected self-centeredness, apart from God and his fellow man. Jesus called him a 'fool', because he lived with his material blessings without God. Luke 12:21 urges us to realise that, '... anyone who stores up things for himself ... is not rich towards God'. Excessive desire for material prosperity could lead to impure and unethical actions (1 Tm 6:9-10). The parable of the rich man and Lazarus (Lk 16:19-31; see also 18:18-30) shows that there is more to life than just living in luxury on earth. Our existence on earth should be to cherish and enjoy the material blessings that God gives, with a view to spending eternity with God.

In as much as Christians desire material blessings, God blesses us in the work we do (with our hands) in obedience and trust - not apart from work. The problem with prosperity gospel followers is that they abuse faith and 'use' God to get instant prosperity without hard work (Pr 6:6-8). The desire is good, but the problem resides in how material things are acquired. The preachers of this gospel target places 'where it itches the most' and followers feel as if they have been truly helped ( $2 \operatorname{Tm} 4: 3)$.

Prosperity gospel appears to offer answers to the plight of the majority wading in poverty and suffering. The truth is, however, that '... prosperity teaching is not really about helping the poor at all, and provides no sustainable answer to the real causes of poverty' (Lausanne Theology Working Group 2010:99). Hughes and Bennet (1998) say the following:

In fact we have to choose between living in order to multiply 'possessions on earth' or 'treasure in heaven'. We have to choose between living to enjoy our money ourselves or living to bless the poor with it. (p. 93)

\section{Engagement points and pastoral guidance in poverty and suffering: correctives and an alternative model of response in Zimbabwe}

It takes determined church leaders and pastors to honestly deal with the Prosperity Gospel Movement. One of the greatest challenges faced with some Zimbabwean Protestant churches is that their pastors are in three ${ }^{14}$ camps in their view of the Prosperity Gospel Movement. The content of the message, the methods employed and the effect it has on the church of God should be a concern to pastors. Below are a few suggested pastoral responses to the Prosperity Gospel Movement in Zimbabwe.

\section{A trend stands or fails the test of time}

First and foremost, it should be clearly understood that prosperity teaching presents itself as a trend that has infiltrated many denominations. As such, a trend should either pass or fail the test of time. In Acts 5:28-33, Peter and the apostles were warned to stop preaching in the name of Jesus. They responded in Acts 5:29, 'We must obey God rather than men'. Upon this stern response, '... they were cut to the quick and were intending to slay them' (Ac 5:33). Gamaliel stood up and cautioned them, referring to trends that had occurred in the past in Acts 5:36-39. He cautioned the men of Israel to recall the acts of Theudas and Judas. Both claimed to be influential and had followers, but they all perished, because what they were doing was not from God. This biblical example clearly teaches that trends should either pass or fail the test of time. For instance, Zimbabweans once witnessed the prosperity movement of the Matthias and Mildret Ministries, which is now silent and cannot be clearly traced. A number of more current ministries are on the decline - one of them is the Spirit Embassy.

\section{A steadfast worship glorifies God}

Second, the shocking social conditions in which this gospel prevails in Zimbabwe are real and the prosperity gospel is trying to bring hope. However, as the Lausanne Theology Working Group Statement on the Prosperity Gospel makes clear (Lausanne Theology Working Group 2010):

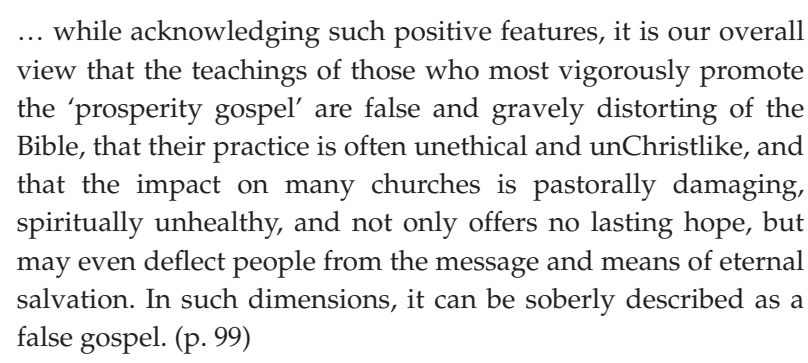

We are urged in Scripture to be content with what we have as we live to honour God with our life situations, because everything material is transient (1 Tm 6:6-7). Piper (2012) says that God is most glorified in our lives, not because we have material prosperity, but when we have a steadfast worship and reverence of him in the midst of poverty, loss and pain. We should worship God as God, not as a giver of cars, money or marriages, as possessions exalt the gifts above the Giver. In no way can material prosperity be substituted for Christ's redemptive work on the cross.

\section{Pastors should faithfully teach and preach God's Word}

Third, Protestant pastors and church leaders in Zimbabwe should continue to faithfully preach and teach God's Word 
without succumbing to the wealth, health and prosperity gospel. Some church members from Protestant and Pentecostal churches change denominations, because they lack depth in their understanding of God's Word. Church members should be taught to distinguish between the solid teaching of God's Word and 'chaff'. Paul teaches that when Christians are grounded in the knowledge of the Son of God they become mature people in Christ. The result of this will be, '... no longer to be children, tossed here and there by waves, and carried about by every wind of doctrine, by trickery of men, by craftiness in deceitful scheming' (Eph 4:13-14).

\section{They call themselves prophets, apostles, fathers and men of God}

Fourth, the leaders of the Prosperity Gospel Movement are branded as prophets, men of God, apostles, fathers, et ceters. But as the Lausanne Theology Working Group (2010) makes clear:

... there are aspects of the lifestyle and behaviour of many preachers of Prosperity Teaching that we find deplorable, unethical, and frankly idolatrous (to the god of Mammon), and in some of these respects we may be called upon to identify and reject such things as the marks of false prophets, according to the standards of the Bible. (p. 101)

Some of the questionable lifestyles mentioned in the Lausanne statement are flamboyant and excessive; wealth and extravagant lifestyles; unethical and manipulative techniques; constant emphasis on money, which is Mammon, as if it were a supreme good; failure to preach the Word of God in a way that feeds the flock of Christ; failure to preach the whole gospel message of sin, repentance, faith and eternal hope, et cetera. Timothy 2:15 challenges us: 'Be diligent to present yourself approved to God as a workman who does not need to be ashamed, handling accurately the word of truth'.

\section{Major errors of cults in Bible interpretation}

Fifth and last, erroneous biblical interpretation has given birth to many cults in the country. Scripture is quoted out of context simply to prove the leader's idea - not God's idea. Jesus never taught his disciples to use prayer to manipulate him or his Father.

Mark 11:24, 'Therefore, I say to you, all things for which you pray and ask believe that you have received them, and they shall be granted to you', is one such passage used by prosperity gospel preachers for their own reasons.

Prosperity gospel preachers and followers engage in prayer for selfish purposes (Ja 3:3-4). They shape prayer according to their desires, and not according to God's will (1 Jn 5:14). As O'Donovan (2000:239) says, 'Prosperity theology is not biblical theology. It is based on an incomplete and incorrect interpretation of what the Bible teaches'.

\section{Conclusion}

The prosperity gospel has lured millions of Zimbabweans into its embrace. Their desire is to be rich in the midst of soaring poverty and unemployment by embracing a 'gospel' that seems to address their social problems. Ironically, the majority of Zimbabweans continue to wallow in a vicious circle of poverty and unemployment. God is manipulated in prayer, faith and giving so that his blessing might be released upon his people. It is a 'gospel' of hopelessness, propelled by the desires of its leaders at the expense of disadvantaged and innocent Zimbabweans. The challenge faced by the current Zimbabwean generation of Christians is to faithfully communicate God's Word to the next generation of Christians. Church leaders and pastors in Protestant denominations must faithfully feed God's flock so that they will be able to distinguish between wheat and chaff. What the prosperity teachers are propagating, is a phenomenon that runs contrary to biblical teaching and is therefore not the gospel.

To curb this phenomenon, one needs to develop and cultivate an appropriate theology that is rooted in historical Christianity as taught in the Bible.

\section{Acknowledgements Competing interests}

The author declares that he has no financial or personal relationships which may have inappropriately influenced him in writing this article.

\section{Authors' contributions}

V.M. conceptualised the study and mapped the outline as well as formulating the core argument. P.M. mined the data and participated in analysis and write up. Both authors contributed equally to the authorship.

\section{References}

Adeleye, F.B., 2011, Preachers of a different Gospel: A Pilgrim's reflections on contemporary trends of Christianity, Hippo Books, Ghana.

Aho Ekue, A.A., 2005, 'Troubled but not destroyed: The development of African theologies and the paradigm of "Theology of reconstruction"', in K. Koschorke (ed.), African identities and World Christianity in the twentieth century, pp. 101112, Harrassowitz Verlag, Wiesbaden.

Atkinson, J., 2008, 'Contemporary Gospels', viewed 10 March 2016, from http://www. cmj-sa.org/Data/Sites/1/pdf/Contemporary-Gospels-3.pdf

Biblical Discernment Ministries, 1996, 'Positive confession/PMA: Prosperity gospel \& the new age', viewed 15 April 2016, from http://www.rapidnet.com/ jbeard/ bdm/Psychology/posit.htm

Bowler, C., 2010, 'Blessed: A history of the American prosperity gospel', PhD thesis, Duke University.

Chawafambira, K., 2013, 'Unemployment tops 70pc', viewed 16 February 2015, from http://www.dailynews.co.zw/articles2013/04/21/unemployment-tops-70pc

Chiumia, S., 2014, 'Zimbabwe's unemployment rate: $4 \%, 60 \%$ or $95 \%$ ? Why data is unreliable', viewed 13 March 2015, from www.africacheck.org/reports/iszimbabwes-unemployment-rate-4

Dames, G.E. \& Dames, G.A., 2009, 'Encountering God's faithfulness in the process of loss', Practical Theology in South Africa 24(2), 1-23.

Fee, G.D., 1994, God's empowering presence: The Holy Spirit in the letters of Paul, Hendrickson Publications, Peabody, MA.

Freeth, B., 2015, 'Impunity Sinking Zimbabwe into poverty, hunger', viewed 13 June 2015, from www.theindependent.co.zw/2015/07/31-impunity-sinkingzimbabwe-into-poverty-hunger

Gehman, R.J., 1989, African traditional religions in biblical perspective, Kesho Publication, Kijabe, Kenya.

Golo, K.W., 2013, 'Africa poverty and its Neo-Pentecostal "Liberators": An ecothological assessment of Africa's prosperity gospellers', Pneuma 35, 366-384. http://dx.doi. org/10.1163/15700747-12341366

Hughes, D. \& Bennet, M., 1998, God of the poor: A biblical vision of God's present rule, OM Publishing, London. 
Isaak, J.P., 2006, Luke, Africa Bible Commentary, Word Alive Publishers, Nairobi.

Jones, D. \& Woodbridge, R.S., 2011, 'Health, wealth and happiness', viewed 15 March 2015, from www.kregel.com/books/pdfs/excerpts/9780825429309.pdf

Kvalbein, H., 2000, 'Poor/poverty', in T.D. Alexander \& B.S. Rosner (eds.), New dictionary of biblical theology, pp. 772-774, InterVarsity Press, Leicester.

Lausanne Theology Working Group, 2010, 'Lausanne theology working group statement on the prosperity gospel', Evangelical Review of Theology 34(2), 99-102.

Louw, D., 2004, A pastoral hermeneutics of care and encounter, 5th edn., Lux Verbi, Wellington.

Louw, D.J., 1998, A pastoral hermeneutics of care and encounter, Lux Verbi, Cape Town.

Louw, D.J., 2011, 'Ta splanchna: A theopaschitic approach to a hermeneutics of God's praxis. From zombie categories to passion categories in theory formation for practical theology of the intestines', HTS Teologiese Studies/Theological Studies 67(3), Art. \#1087, 13 pages. http://dx.doi.org/10.4102/hts.v67i3.1087

MacArthur, J.F., Jr., 1992, Charismatic Chaos, Zondervan, Publishing House, MI.

Maxwell, D., 1998, 'Delivered from the spirit of poverty: Pentecostalism, prosperity and modernity in Zimbabwe', Journal of Religion in Africa 28(3), 350-373. http:// dx.doi.org/10.2307/1581574

Mbiti, J., 1986, Bible and theology in African Christianity, Oxford University Press, Nairobi.

Mikhaiel, N., 1992, The Toronto blessing and slaying in the spirit the telling wonder, Southville Press, Marrickville, NSW.

Mohan, M., 2015, 'What factors contributed to the hyperinflation of the Zimbabwean dollar', viewed 13 March 2015, from https://www.quora.com/What-factorscontributed-to-the-hyperinflation-of-the-Zimbabwean-Dollar

Moyo, R., 2011, 'Unemployment in Zimbabwe', viewed 16 September 2015, from www.bulawayo24.com/index-d-opinions-s-columist-byo-7524.htm

Mushekwe, I., 2013, 'Pastor alleges prophets Makandiwa and Angels received ritual charm', viewed 1 January 2016, from www.nehandaradio.com2013/07/01pastor-alleges-prophets-makandiwa-and-angels-received-ritual-charm

Nyirongo, L., 1997, The gods of Africa or The God of the Bible? The snares of African traditional religion in Biblical perspective, IRS, Potchefstroom.
O'Donovan, W., 2000, Biblical Christianity in Modern Africa, Paternoster Press, Cumbria.

Phiri, I. \& Maxwell, J., 2007, 'Gospel riches', Christianity Today, 6 July, pp. 23-29.

Pindula site, 2015, 'Emmanuel Makandiwa', viewed 15 September 2015, viewed n.d., from www.pindula.co.zw/emmanuelmakandiwa

Piper, J., 2012, 'Prosperity gospel', viewed 10 March 2015, from www.youtube.com./ watch? $v=\mathrm{G}=\mathrm{v} \_91 \mathrm{c5} 0 \mathrm{ju}$.

Reader, J., 2008, Reconstructing practical theology: The impact of globalization, Ashgate, Aldershot.

Sarles, K.L., 1986, 'A theological evaluation of the prosperity gospel', Bibliotheca Sacra 143(572), 329-352.

Staff Reporter (for online news), 2015, 'Prophet Magaya', The Zimbabwean, viewed 15 September 2015, from www.thezimbabweannewsalive.com/uncategorized/ prophet-magaya vast Property-empire and secrets-revealed.

Talbert, C.H., 2010, Matthew, Baker Academic, MI.

The Standard, 2015, 'Prophecy on Zimbabwe', viewed 15 September 2015, from www. myzimbabwe.co.zw/news/4007-latest-on-prophet-makandiwa.html.

Torrance, T.F., 2009, Atonement: The person and work of Christ, IVP Academic, Downers Grove, IL.

Tucker, R.A., 1989, Another gospel: Cults, alternative religions and the new age movement, Zondervan Publishing House, MI.

Wafawarova, R., 2015, 'The curse of prosperity gospel', The Herald, viewed 20 February 2015, from www.hearlad.co.zw/theCurse-of-prosperity-gospel/

Wise, R., 2015, 'Move over Bob Tilton, Creflo Dollar is in the house!', viewed 10 February 2016, from http://www.forgottenword.org/dollar.html

Witherington, B., III, 2010, Jesus and money, SPCK, Great Britain.

Young, P., 2015. 'What God says about prosperity', viewed 5 December 2015, from http://drawingotherstochrist.com/text_sermon/prosperity.pdf

Zvauya, C. \& Muperi, W., 2015, 'ARV default blamed on churches n'angas', viewed 10 December 2015, from https://www.dailynews.co.zw/articles/2015/02/10/arvdefault-blamed-on-churches-n-angas 